\title{
WF-10129, A NOVEL ANGIOTENSIN CONVERTING ENZYME INHIBITOR PRODUCED BY A FUNGUS, DORATOMYCES PUTREDINIS
}

\author{
Takeshi Ando, Satoshi Okada, Itsuo Uchida, Keij Hemmi, \\ Motoaki Nishikawa, Yasuhisa Tsurumi, Akimiko Fujie, \\ KeIzo Yoshida and Masakuni OKuHara \\ Exploratory Research Laboratories, Fujisawa Pharmaceutical Co., Ltd., \\ Ibaraki 300-26, Japan
}

(Received for publication November 12, 1986)

\begin{abstract}
WF-10129 is an angiotensin converting enzyme (ACE) inhibitor produced by Doratomyces putredinis. $\mathrm{IC}_{50}$ of the compound is $1.4 \times 10^{-8} \mathrm{M}$ for the ACE activity. WF-10129 was purified from cultured filtrate by successive ion exchange chromatography and HPLC. The chemical structure 1 was elucidated on the basis of spectroscopic and chemical evidence. The compound is a dipeptide composed of L-tyrosine and a novel amino acid. WF-10129 inhibits the pressor response of angiotensin I when administered intravenously at $0.3 \mathrm{mg} / \mathrm{kg}$ in rats.
\end{abstract}

Since the discovery and development of captopril as a clinically important anti-hypertensive drug, many research groups have screened for novel angiotensin converting enzyme (ACE) inhibitors from microbial products. Many compounds which belong to a variety of chemical entities have been reported $^{1 \sim 11)}$. We recently discovered WF-10129 during our screening program searching for novel angiotensin converting enzyme inhibitor from fungal products. This paper describes taxonomic studies on the producing strain, fermentation and isolation procedures. We also describe the structural elucidation of WF-10129 and biological characterization of the inhibitor.

\section{Materials and Methods}

\section{Fermentation}

Seed flasks ( $500 \mathrm{ml}$ ), containing $100 \mathrm{ml}$ of the seed medium consisting of corn starch $3 \%$, gluten meal $1 \%$, cotton seed flour $1 \%$, dried yeast $1 \%$, corn steep liquor $1 \%$ and $\mathrm{CaCO}_{3} 0.2 \%$ were inoculated with growth from a well-grown slant culture of Doratomyces putredinis F-10129. The flasks were shaken on a rotary shaker $\left(220 \mathrm{rpm}, 5.1 \mathrm{~cm}\right.$-throw) for 4 days at $25^{\circ} \mathrm{C}$. The content of the flasks was used to inoculate 20 liters of fermentation medium in a 30-liter stainless steel fermentor. The composition of the production medium was as follows; corn starch $4 \%$, gluten meal $3 \%$, dried yeast $0.5 \%$, $\mathrm{MgSO}_{4} \cdot 7 \mathrm{H}_{2} \mathrm{O} 0.05 \%$ and $\mathrm{CaSO}_{4} \cdot 2 \mathrm{H}_{2} \mathrm{O} 0.2 \%$. The $\mathrm{pH}$ of the medium was adjusted to 7.0 before sterilization. Fermentation was allowed to proceed for 7 days at $25^{\circ} \mathrm{C}$. At 3 days of cultivation, $400 \mathrm{~g}$ of glucose was added to the fermentator. The production of active compound in the fermentation broth was monitored by measuring its enzyme inhibitory activity.

\section{ACE Assay}

The ACE activity was measured fluorimetrically according to the method of CARMEL et al. ${ }^{123}$ with slight modification. $o$-Aminobenzoylglycyl- $p$-nitro-L-phenylalanyl-L-proline $\left(\mathrm{ABz}-\mathrm{Gly}\right.$-Phe $\left(\mathrm{NO}_{2}\right)$-Pro) was used as a substrate and diluted guinea pig serum was used as an enzyme source. The substrate was synthesized in our laboratories. In the routine assay, $200 \mu 1$ of substrate solution containing 0.58 $\mathrm{mM}$ of $\mathrm{ABz}-\mathrm{Gly}-\mathrm{Phe}\left(\mathrm{NO}_{2}\right)$-Pro, $1 \mathrm{M} \mathrm{NaCl}$ and $0.2 \mathrm{M}$ Tris- $\mathrm{HCl}$ buffer, $\mathrm{pH} 8.2$, was mixed with $10 \mu \mathrm{l}$ of fermentation broth and $40 \mu \mathrm{l}$ of diluted guinea pig serum. In the kinetic studies of Dixon plot or Lineweaver-Burk plot, $150 \mu 1$ of substrate solution which contained several concentration of ABz- 
Gly-Phe $\left(\mathrm{NO}_{2}\right)$-Pro, $1 \mathrm{M} \mathrm{NaCl}$ and $0.2 \mathrm{M}$ Tris- $\mathrm{HCl}$ buffer, $\mathrm{pH} 8.2$, was mixed with $50 \mu 1$ of inhibitor solution and $50 \mu$ of diluted guinea pig serum.

The Pressor Response of Angiotensin I

A group of four male Sprague-Dowley rats ( 7 weeks old) was anesthetized with urethan (700 $\mathrm{mg} / \mathrm{kg}$, ip) and the mean arterial blood pressure was recorded from femoral artery via polyethylene catheter connected to the pressure tranducer which was coupled to a Biophysiograph 180 system (Nihondenki-San-Ei Instrument Co., Ltd.). Drug and angiotensin I were administered intravenously from the cannula which was introduced into the femoral vein. The inhibition of a pressure response provoked by $1 \mu \mathrm{g} / \mathrm{kg}$ iv angiotensin I was assessed.

\section{Results}

Identification of Strain F-10129

The strain F-10129 was originally isolated from a soil sample collected at Ayabe City, Kyoto Prefecture, Japan.

The strain F-10129 was a hyphomycete fungus, and formed mononematous and synnematous anamorphs on various culture media. The conidiogenesis was holoblastic, and the conidiogenous cell development was percurrent. Its mycological characteristics were as follows.

The synnemata, measuring $150 \sim 400 \times 10 \sim 30 \mu \mathrm{m}$, consisted of a sterile stalk and a fertile head, and produced dry conidial columnars up to $800 \mu \mathrm{m}$ in length (Fig. 1). The conidiophores were formed from aerial hyphae as right angle branches or at the upper quarter part of synnemata, and verticillately branched in penicillate fashion. They were hyaline, smooth, $70 \sim 150 \mu \mathrm{m}$ long and $4 \sim 5 \mu \mathrm{m}$ thick, and formed one to five annellophores at the tip of each branch. The annellophores were hyaline, smooth, lageniform to cylindrical, $7 \sim 15 \mu \mathrm{m}$ long and $3 \sim 4 \mu \mathrm{m}$ thick. The conidia were produced in long basipetal chains forming pale yellow columnars. They were hyaline, smooth, unicellular, ellipsoidal to ovoid, rounded at the apex and truncated at the base, $3.5 \sim 8 \mu \mathrm{m}$ long and $2 \sim 4 \mu \mathrm{m}$ thick.

Colonies on Potato dextrose agar (Difco) grew restrictedly, attaining $2.0 \mathrm{~cm}$ in diameter after two weeks at $25^{\circ} \mathrm{C}$, and the surface was plane, thin, powdery and pale yellow. The reverse of the colony was the same. This strain could grow at a temperature range from 4 to $35^{\circ} \mathrm{C}$ with optimum growth

Fig. 1. Scanning electron micrograph of anamorph of the strain F-10129.

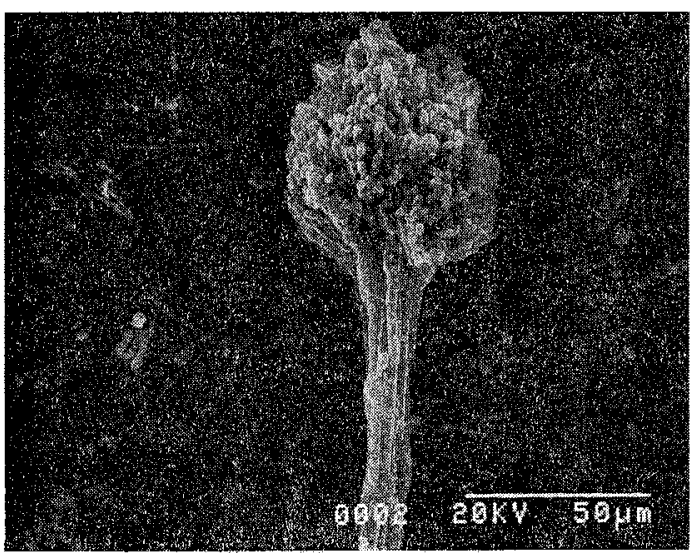
at $26^{\circ} \mathrm{C}$.

By comparison of the above-mentioned characteristics with the description of UDAGAWA and HORIE ${ }^{132}$, the strain F-10129 was identified as one strain of Doratomyces putredinis (Corda) Morton et G. Smith, and named Doratomyces putredinis F-10129. This strain was deposited in the Fermentation Research Institute, Agency of Industrial Science and Technology, Japan, as FERM P-7302.

\section{Production of WF-10129 by Doratomyces putredinis}

The growth of Doratomyces putredinis was monitored by packed mycelium volume measured 
by centrifugation of cultured broth at $3,000 \mathrm{rpm}$ for 10 minutes.

The production of WF-10129 was monitored by the inhibition of angiotensin converting enzyme and assessed from the standard curve of the purified WF-10129. A time course of WF-10129 production is shown in Fig. 2. The production of WF-10129 was increased by addition of $2 \%$ of sterilized glucose $(400 \mathrm{~g} / 20$ liter medium) at 3 days of cultivation. Maximum production of WF-10129 at 6 days was approximately $10 \mu \mathrm{g} / \mathrm{ml}$.

\section{Isolation and Characterization}

The procedures of the isolation are summarized in Fig. 3. The cultured broth was filtered with the aid of diatomaceous earth. The filtrate (40 liters) was applied to a column of Dowex 1-X2 $\left(\mathrm{OH}^{-}\right)$. The active principle was eluted with $0.1 \mathrm{~N} \mathrm{HCl}$ solution after washing the column with $0.3 \mathrm{~N} \mathrm{NaOH}$ solution. The eluate was passed through a column of Dowex 50W-X2 $\left(\mathrm{H}^{+}\right)$. The column was washed with $0.05 \mathrm{M} \mathrm{NaCl}$ and the activity was eluted with $0.1 \mathrm{M} \mathrm{NaCl}$. The eluate was adsorbed to activated carbon and the active principle was eluted with $80 \%$ aqueous acetone. The desalted eluate was charged on a column of DEAE-Sephadex A-25 $\left(\mathrm{PO}_{4}^{---}\right)$and eluted with $0.03 \mathrm{M} \mathrm{NaCl}$ after washing the column with $0.01 \mathrm{M} \mathrm{NaCl}$. The active fraction was adjusted to $\mathrm{pH} 2.0$ with $6 \mathrm{~N} \mathrm{HCl}$

Fig. 2. Time course of WF-10129 production.

- Potency, $\mathrm{OpH}, \triangle$ packed mycelium volume (PMV).

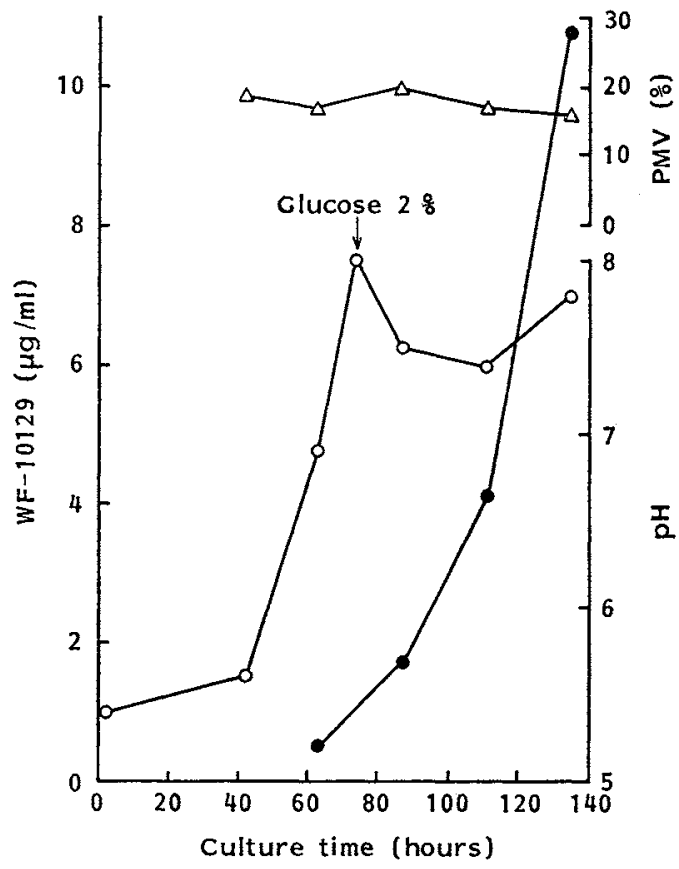

Fig. 3. Isolation procedure of WF-10129.

$$
\begin{aligned}
& \text { Filtrate } \\
& 1 \\
& \text { Dowex 1-X2 }\left(\mathrm{OH}^{-}\right) \\
& \text {eluted with } 0.1 \mathrm{~N} \mathrm{HCl} \\
& \text { Dowex 50W-X2 }\left(\mathrm{H}^{+}\right) \\
& \text {eluted with } 0.1 \mathrm{M} \mathrm{NaCl}
\end{aligned}
$$

Table 1. Isolation of WF-10129 by HPLC.

\begin{tabular}{ll}
\hline Stationary phase & Cosmosil $\mathrm{C}_{18}$ \\
& $(10 \times 250 \mathrm{~mm}$, Nakarai Chemicals Co., Ltd. $)$ \\
Mobile phase & $8 \%$ Acetonitrile in $0.05 \%$ TFA \\
Flow rate & $5 \mathrm{ml} /$ minute \\
Detector & UV at $254 \mathrm{~nm}$ \\
Retention time & 20 minutes \\
\hline
\end{tabular}


and adsorbed to Diaion HP-20 for desalting and the activity was eluated with $70 \%$ aqueous $\mathrm{MeOH}$. The eluate was concentrated in vacuo to a small volume and was chromatographed on a column of CMSephadex C-25 $\left(\mathrm{H}^{+}\right)$and eluted with $\mathrm{H}_{2} \mathrm{O}$. The active fraction was subjected to a column chromatography of Sephadex G-15 and developed with $1 \%$ acetic acid solution. The active fractions were combined and purified by preparative HPLC. HPLC was carried out on the condition summarized in Table 1. The active fractions obtained by HPLC was lyophilized to give a white powder. The yield from 40 liters filtrate was $17 \mathrm{mg}$.

Physico-chemical Properties and Structural Elucidation

The physico-chemical properties of WF-10129 (1) are summarized in Table 2. The amphoteric substance, WF-10129, which is soluble in $\mathrm{H}_{2} \mathrm{O}$ and $\mathrm{MeOH}$, while insoluble in hexane, benzene and

Table 2. Physico-chemical properties of WF-10129 (1).

\begin{tabular}{|c|c|}
\hline Appearance & Colorless powder \\
\hline $\mathrm{MP}$ & $90 \sim 95^{\circ} \mathrm{C}$ \\
\hline Molecular formula & $\mathrm{C}_{20} \mathrm{H}_{28} \mathrm{~N}_{2} \mathrm{O}_{8}$ \\
\hline SI-MS $(m / z)$ & $425(\mathrm{M}+\mathrm{H})^{+}, 447(\mathrm{M}+\mathrm{Na})^{+}$ \\
\hline Specific rotation & {$[\alpha]_{\mathrm{D}}^{23}+12.9^{\circ}\left(c 0.375, \mathrm{H}_{2} \mathrm{O}\right)$} \\
\hline UV $\lambda_{\max }^{\mathrm{H}_{\mathrm{m}}, \mathrm{O}} \mathrm{nm}(\varepsilon)$ & $275(1,060), 280(930)$ \\
\hline$\lambda_{\mathrm{max}}^{\mathrm{H}_{2} \mathrm{O} \mathrm{O}}+\mathrm{HCl} \mathrm{nm}$ & 275,280 \\
\hline$\lambda_{\max }^{\mathrm{H}_{\mathrm{O}} \mathrm{O}}+\mathrm{NaOH} \mathrm{nm}$ & $277,283,292$ \\
\hline IR $\nu_{\max }^{\mathrm{KBR}} \mathrm{cm}^{-1}$ & $\begin{array}{l}3350,2950,3000 \sim 2300(\mathrm{br}), 1720,1680,1620,1540,1520 \\
1445,1380,1350,1260,1230,1110,910,880,830\end{array}$ \\
\hline \multicolumn{2}{|l|}{ TLC* (Rf value) } \\
\hline $\mathrm{BuOH}-\mathrm{AcOH}-\mathrm{H}_{2} \mathrm{O}(4: 1: 2)$ & 0.4 \\
\hline 2-PrOH $-\mathrm{H}_{2} \mathrm{O}(8: 2)$ & 0.6 \\
\hline
\end{tabular}

* Stationary phase: Silica gel sheet.

Table 3. ${ }^{13} \mathrm{C}$ NMR chemical shifts (ppm) and multiplicities in $\mathrm{D}_{2} \mathrm{O}$ for WF-10129 (1).

\begin{tabular}{|c|c|c|}
\hline $\begin{array}{c}\text { Chemical } \\
\text { shift }\end{array}$ & $\begin{array}{l}\text { Multi- } \\
\text { plicity }\end{array}$ & Assignment \\
\hline 211.0 & $\mathrm{~s}$ & $-\mathrm{CO}-$ \\
\hline 174.7 & $\mathbf{s}$ & \\
\hline 171.2 & s & $-\operatorname{COO}(N)-$ \\
\hline 169.4 & s & \\
\hline 155.1 & $\mathrm{~s}$ & \\
\hline $131.2(\times 2)$ & $\mathrm{d}$ & \\
\hline 129.1 & s & \\
\hline $116.0(\times 2)$ & $d$ & \\
\hline 67.5 & $\mathrm{~d}$ & $-\stackrel{+}{\mathrm{C}} \mathrm{HOH}$ \\
\hline 58.2 & $\mathrm{~d}$ & \\
\hline 56.7 & $\mathrm{~d}$ & $-\mathrm{NHCHCO}-$ \\
\hline 54.7 & $d$ & \\
\hline 42.2 & $\mathrm{t}$ & \\
\hline 38.5 & $\mathrm{t}$ & \\
\hline 36.9 & $\mathrm{t}$ & $-\mathrm{CH}_{2}^{-}$ \\
\hline 32.1 & $\mathrm{t}$ & \\
\hline 22.3 & $q$ & $-\mathrm{CH}_{2}$ \\
\hline 16.7 & $q$ & \\
\hline
\end{tabular}

Fig. 4. The partial structures $A \sim D$ and the ${ }^{1} \mathrm{H}-{ }^{1} \mathrm{H}$ relationships $(\mathrm{Hz})$ in 1.

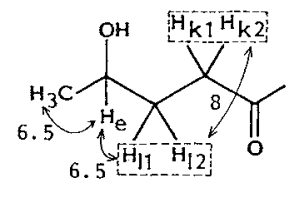

A

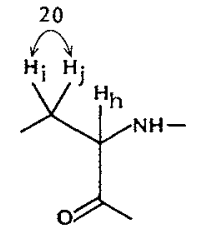

B

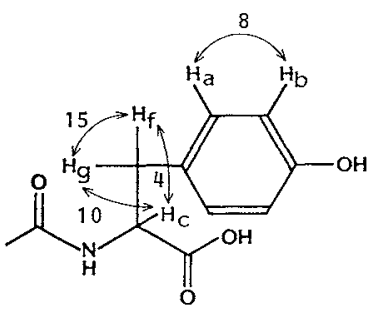

D 
Table 4. 'H NMR chemical shifts, multiplicities, and coupling constants $(J, \mathrm{~Hz})$ for 1 and 3.

\begin{tabular}{|c|c|c|c|c|c|c|}
\hline Proton & & $\mathbf{1}^{\mathrm{a}}$ & & & $\mathbf{3}^{b}$ & \\
\hline $\mathrm{a}$ & 7.17 & $\mathrm{~d}$ & $(2 \mathrm{H}, J=8)$ & 7.16 & $\mathrm{~d}$ & $(2 \mathrm{H}, J=8)$ \\
\hline $\mathrm{b}$ & 6.83 & $\mathrm{~d}$ & $(2 \mathrm{H}, J=8)$ & 7.00 & d & $(2 \mathrm{H}, J=8)$ \\
\hline c & 4.75 & dd & $(J=10,4)$ & 4.80 & $\mathrm{~m}$ & \\
\hline d & 4.08 & $\mathrm{q}$ & $(J=7)$ & 3.20 & $\mathrm{~m}$ & \\
\hline e & 3.79 & $\mathrm{~m}$ & & 4.89 & $\mathrm{~m}$ & \\
\hline $\mathrm{f}$ & 3.32 & dd & $(J=15,4)$ & 3.20 & & \\
\hline g & 2.78 & dd & $(J=15,10)$ & & $\mathrm{m}$ & $(2 \mathrm{H})$ \\
\hline h. & 2.97 & $\mathrm{~m}$ & $(2 \mathrm{H})$ & 3.53 & $\mathrm{t}$ & $(J=6)$ \\
\hline $\begin{array}{l}\mathrm{i} \\
\mathrm{j}\end{array}$ & 3.17 & dd & $(J=20,6.5)$ & 2.79 & d & $(2 \mathrm{H}, J=6)$ \\
\hline $\begin{array}{l}\mathrm{k} 1 \\
\mathrm{k} 2\end{array}$ & 2.55 & $t$ & $(2 \mathrm{H}, J=8)$ & 2.43 & $\mathrm{~m}$ & $(2 \mathrm{H})$ \\
\hline 11 & 1.67 & $\mathrm{~m}$ & $(2 \mathrm{H})$ & 1.82 & $\mathrm{~m}$ & $(2 \mathrm{H})$ \\
\hline $\begin{array}{l}12 \\
\mathrm{~m}\end{array}$ & 1.52 & d & $(3 \mathrm{H}, J=7)$ & $1.21^{\circ}$ & d & $(3 \mathrm{H}, J=7)$ \\
\hline $\mathrm{n}$ & 1.16 & d & $(3 \mathrm{H}, J=6.5)$ & $1.22^{\mathrm{e}}$ & d & $(3 \mathrm{H}, J=7)$ \\
\hline o & & & & 7.90 & $d$ & $(J=8)$ \\
\hline \multirow[t]{2}{*}{$\mathrm{COOCH}_{3}$} & & & & 3.74 & $\mathrm{~s}$ & $(3 \mathrm{H})$ \\
\hline & & & & 3.70 & $s$ & $(3 \mathrm{H})$ \\
\hline \multirow[t]{2}{*}{$\mathrm{OCOCH}_{3}$} & & & & 2.29 & $\mathrm{~s}$ & $(3 \mathrm{H})$ \\
\hline & & & & 2.02 & s & $(3 \mathrm{H})$ \\
\hline
\end{tabular}

$400 \mathrm{MHz}, \mathrm{CD}_{3} \mathrm{OD}-\mathrm{D}_{2} \mathrm{O}$.

b $200 \mathrm{MHz}, \mathrm{CDCl}_{3}$.

- Assignments may be interchanged.

$\mathrm{CHCl}_{3}$, gave a positive reaction to ninhydrin, Molish, cerium sulfate and iodine, though negative to Dragendorff reagents. The ${ }^{13} \mathrm{C}$ NMR spectrum $\left(\mathrm{D}_{2} \mathrm{O}\right.$, Table 3$)$ of 1 showed in the $\mathrm{sp}^{2}-$ carbon region 8 signals including four carbonyl carbon signals, one (211.0 (s) ppm) of which is attributable to a ketone function. The remaining<smiles>CC(O)CCC(=O)CC(NC(C)C(=O)NC(Cc1ccc(O)cc1)C(=O)O)C(=O)O</smiles>

$\mathbf{1}$ four signals at $155.1(\mathrm{~s}), 131.2(\mathrm{~d} \times 2), 129.1(\mathrm{~s})$, $116.0(\mathrm{~d} \times 2) \mathrm{ppm}$ indicated the presence of 1,4-disubstituted phenyl ring in 1 . In the $\mathrm{sp}^{3}$-carbon region ten signals were assignable to one secondary alcohol carbon (67.5 (d) ppm), three $\alpha$-amino acid carbons (58.2 (d), 56.7 (d), 54.7 (d) ppm), four methylene carbons (42.2 (t), $38.5(\mathrm{t}), 36.9(\mathrm{t}), 32.1(\mathrm{t}) \mathrm{ppm})$ and two methyl carbons (22.3 (q), 16.7 (q) ppm). These data together with secondary ion mass spectrum (SI-MS) data (Table 2) disclosed the molecular formula $\left(\mathrm{C}_{20} \mathrm{H}_{28} \mathrm{~N}_{2} \mathrm{O}_{8}\right)$ of $\mathbf{1}$.

Extensive spin decoupling of the $400 \mathrm{MHz}{ }^{1} \mathrm{H}$ NMR spectra (Table 4) of 1 revealed ${ }^{1} \mathrm{H}-{ }^{1} \mathrm{H}$ relationships as shown in Fig. 4, leading to partial structures A, B, C and D, which are quite consistent with the ${ }^{13} \mathrm{C}$ NMR data described above. The units $\mathrm{C}$ and $\mathrm{D}$ were confirmed by the fact that hydrolysis of 1 with $6 \mathrm{~N} \mathrm{HCl}\left(110^{\circ} \mathrm{C}, 22\right.$ hours) gave after chromatography on ion-exchange column of Dowex 50W-X8 (0.2 M pyridine- $\mathrm{AcOH}, \mathrm{pH}$ 3.07) L-alanine and L-tyrosine (ca. 1:1), which were identified by comparison with authentic samples in amino acid analysis and $\mathrm{CD}$ spectra. 1 was subjected to hydrazinolysis $\left(100^{\circ} \mathrm{C}, 6\right.$ hours) to provide tyrosine as a sole amino acid product, indicating that L-tyrosine contained in peptide 1 is located at the $C$-terminus. 


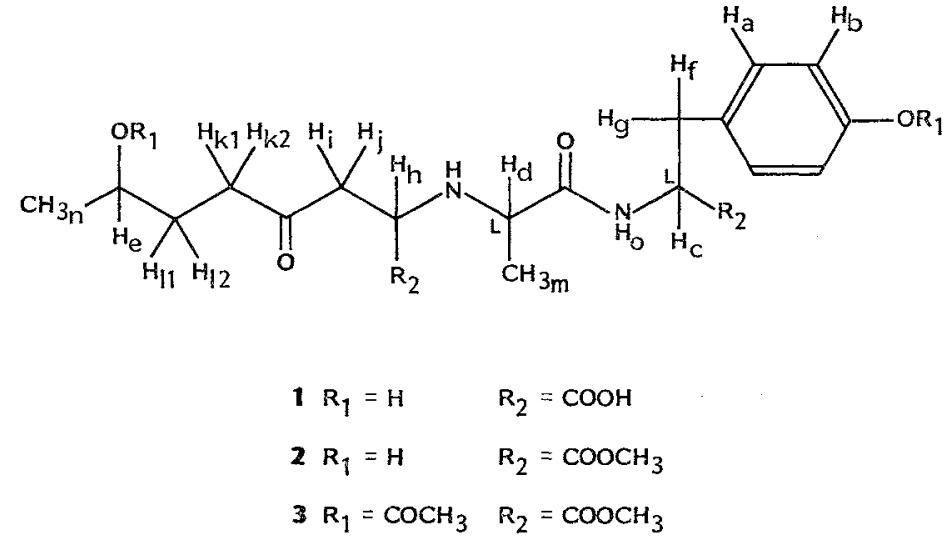

Fig. 5. Fragmentations in the FAB- and SI-MS of 1.<smiles>CC(O)CCC(=O)CC(NC(C)C(=O)NC(Cc1ccc(O)cc1)C(=O)O)C(=O)O</smiles>

Fig. 7. Lineweaver-Burk plot of inhibition of $\mathrm{ACE}$ by WF-10129.

WF-10129 concentration: No inhibitor, O WF-10129 $\left(1 \times 10^{-8} \mathrm{M}\right), \Delta$ WF-10129 $\left(2 \times 10^{-8} \mathrm{M}\right)$.

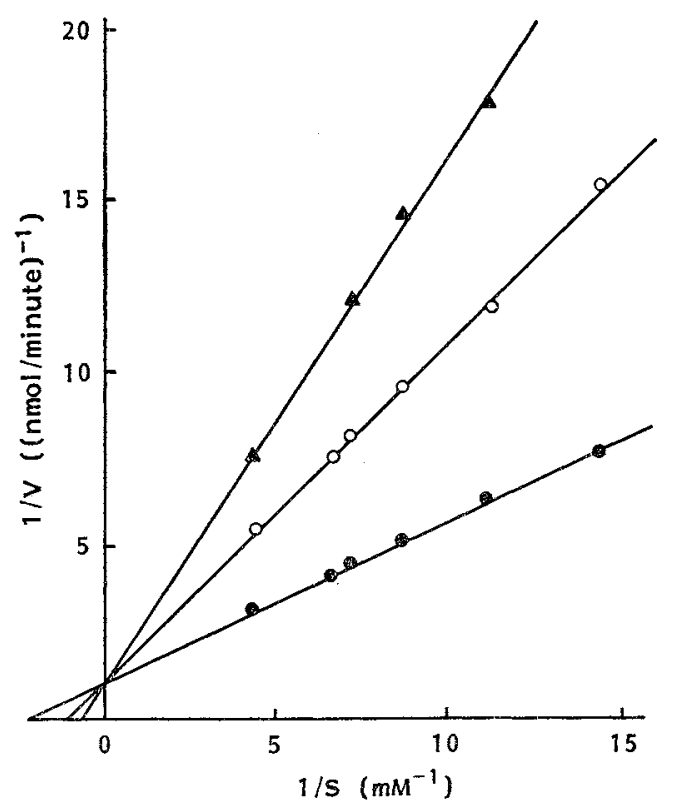

Fig. 6. Dixon plot of inhibition of ACE by WF10129.

Substrate concentration (ABz-Gly-Phe $\left(\mathrm{NO}_{2}\right)$ Pro): $0.23 \mathrm{~mm}, 00.115 \mathrm{~mm}$.

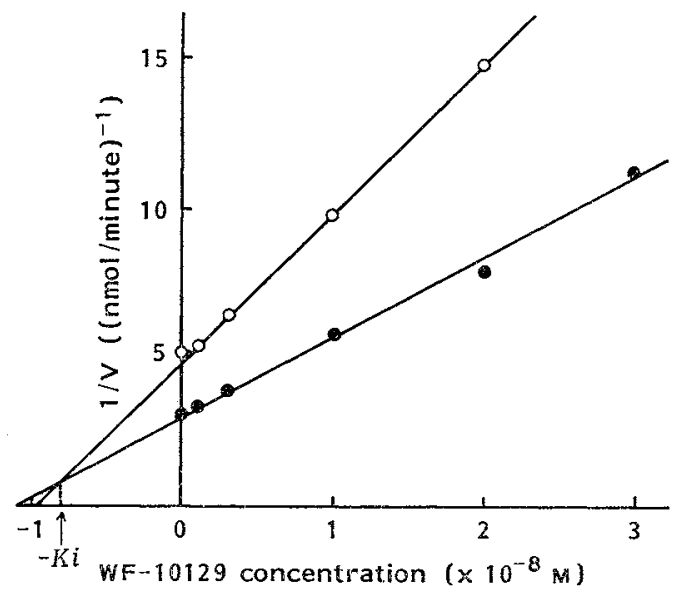

Treatment of 1 with excess $\mathrm{CH}_{2} \mathrm{~N}_{2}$ in $\mathrm{MeOH}$ ether for 10 minutes at $0^{\circ} \mathrm{C}$ gave a dimethyl ester derivative 2 (field desorption mass spectra (FDMS) $m / z 453(\mathrm{M}+\mathrm{H})^{+}, 475(\mathrm{M}+\mathrm{Na})^{+}$; IR $\left(\mathrm{CHCl}_{3}\right) \mathrm{cm}^{-1} 1735,1660$; ${ }^{1} \mathrm{H}$ NMR $\left(\mathrm{CDCl}_{3}\right)$ $3.68(3 \mathrm{H}, \mathrm{s}), 3.76(3 \mathrm{H}, \mathrm{s}))$, which was acetylated with $\mathrm{Ac}_{2} \mathrm{O}$ - pyridine (room temperature 20 hours) to lead to the diacetyl dimethyl ester derivative 3 (SI-MS $m / z 537(\mathrm{M}+\mathrm{H})^{+}$; ninhydrin positive). The ${ }^{1} \mathrm{H}$ NMR spectrum $\left(\mathrm{CDCl}_{3}\right)$ of 3 was analyzed with the aid of spin decoupling experiments and ${ }^{1} \mathrm{H}$ shift correlation spectrum, resulting in the assignments of proton signals as shown in Table 4. 
Table 5. Inhibition of angiotensin I pressor response by WF-10129 in rats.

\begin{tabular}{cccc}
\hline \multirow{2}{*}{ Dose } & \multicolumn{3}{c}{ Inhibition $(\%) \begin{array}{c}\text { of angiotensin } \mathrm{I}^{*} \text { response } \\
(\text { mean } \pm \mathrm{SE}, n=4)\end{array}$} \\
\cline { 2 - 4 } & 10 minutes & 40 minutes & 50 minutes \\
\hline $300 \mu \mathrm{g} / \mathrm{kg}$ iv & $74.4 \pm 5.9$ & $36.9 \pm 6.5$ & $25.8 \pm 10.3$ \\
\hline$* 1 \mu \mathrm{g} / \mathrm{kg}$ iv. & & &
\end{tabular}

In this ${ }^{1} \mathrm{H}$ shift correlation spectrum, a long range coupling between two methylene protons resonated at $2.43\left(\mathrm{H}_{\mathrm{k} 1}\right.$ and $\left.\mathrm{H}_{\mathrm{x} 2}\right)$ and $2.79\left(\mathrm{H}_{\mathrm{i}}\right.$ and $\left.\mathrm{H}_{\mathrm{j}}\right) \mathrm{ppm}$ was observed. These data made it possible to connect the partial structures A, B, C and D in WF-10129 and to lead to the full structure 1. The deduced structure 1 was assisted by analysis of fragmentation peaks in the fast atom bombardment (FAB)- and SI-MS as shown in Fig. 5.

\section{Biochemical Properties}

WF-10129 inhibited $\mathrm{ACE}$ in a dose dependent manner and $\mathrm{IC}_{50}$ was $1.4 \times 10^{-8} \mathrm{M} . \quad \mathrm{IC}_{50}$ for captopril was $1.7 \times 10^{-8} \mathrm{M}$ when assessed in the same experiment. The kinetic study of WF-10129 was carried out and Dixon plot and Lineweaver-Burk plot for ACE inhibition are shown in Figs. 6 and 7 . WF-10129 was a competitive inhibitor of ACE with a $K i$ value of $8 \times 10^{-9} \mathrm{M}$.

\section{Inhibition of the Pressor Response Induced by Angiotensin I}

WF-10129 was tested intravenously at a dose of $0.3 \mathrm{mg} / \mathrm{kg}$ in anesthetized normotensive rats. As shown in Table 5, WF-10129 inhibited the angiotensin I induced pressor response significantly but did not reveal any effect on angiotensin II $(0.3 \mu \mathrm{g} / \mathrm{kg})$ induced pressor response.

\section{Discussion}

Most of the currently reported ACE inhibitors of microbial origin were produced by the strains of actinomycetes ${ }^{2 \sim 11)}$ and only aspergillomarasmines A and $\mathbf{B}$ were originated from the culture broth of a fungus ${ }^{1}$. WF-10129 was isolated as a fungal product of Doratomyces putredinis. The structure was deduced to be a novel dipeptide shown as 1. $\mathrm{IC}_{50}$ of $\mathrm{WF}-10129$ for $\mathrm{ACE}$ is $1.4 \times 10^{-8} \mathrm{M}$ and the potency is almost the same with that of captopril, indicating WF-10129 is one of the most potent ACE inhibitor which has been isolated from microbial product. It is of interest to note that WF-10129 (1), an ACE inhibitor found from microbial origin is a substituted $N$-carboxymethyl dipeptide which is similar in structure ${ }^{14)}$ with the synthetic potent ACE inhibitor MK421, enalapril.

\section{Acknowledgment}

The authors are indebted to Drs. H. IMANAKA, H. AoKI and M. KoHSAKa for their encouragement throughout this work. We are grateful to Ms. K. NitTA, Y. NoGUCHI and A. OGATA for their excellent technical assistance. We wish to thank Miss C. FuxUDA for the preparation of this manuscript.

\section{References}

1) Mikami, Y. \& T. Suzuki: Novel microbial inhibitors of angiotensin-converting enzyme. Aspergillomarasmines A and B. Agric. Biol. Chem. 47: 2693 2695, 1983

2) Kasai, N.; K. Fukuhara, K. Oda \& S. Murao: Inhibition of angiotensin I converting enzyme and carboxypeptidase A by FMPI, Talopeptin, and their derivatives. Agric. Biol. Chem. 47: 2915 2916, 1983

3) Kido, Y.; T. Hamakado, T. Yoshida, M. Anno, Y. Motoki, T. WaKamiya \& T. Shiba: Isolation and characterization of ancovenin, a new inhibitor of angiotensin I converting enzyme, produced by actino- 
mycetes. J. Antibiotics 36: 1295 1299, 1983

4) Bush, K.; P. R. Henry \& D.S. SlusarchyK: Muraceins-Muramyl peptides produced by Nocardia orientalis as angiotensin-converting enzyme inhibitors. I. Taxonomy, fermentation and biological properties. J. Antibiotics 37: 330 335, 1984

5) Huang, L.; G. Rowin, J. Dunn, R. Sykes, R. Dobna, B. A. Mayles, D. M. Gross \& R. W. Burg: Discovery, purification and characterization of the angiotensin converting enzyme inhibitor, L-681, 176, produced by streptomyces sp. MA 5143a. J. Antibiotics 37:462 465, 1984

6) Kido, Y.; T. HamaKado, M. Anno, E. Miyagawa, Y. Motoki, T. WakamiYa \& T. Shiba: Isolation and characterization of 15B2, a new phosphorus containing inhibitor of angiotensin I converting enzyme produced by Actinomadura sp. J. Antibiotics 37: 965 969, 1984

7) Bush, K.; P. R. Henry, M. Souser-Woehleke, W. H. Trejo \& D. S. Slusarchyk: Phenacein-An angiotensin-converting enzyme inhibitor produced by a streptomycete. I. Taxonomy, fermentation and biological properties. J. Antibiotics 37: 1308 1312, 1984

8) O'CONNOR, S. \& P. Somers: Methods for the detection and quantitation of angiotensin converting enzyme inhibitors in fermentation broths. J. Antibiotics 38: $993 \sim 996,1985$

9) Umezawa, H.; T. Aoyagi, K. Ogawa, T. Obata, H. Iinuma, H. Naganawa, M. Hamada \& T. TakeUCHI: Foroxymithine, a new inhibitor of angiotensin-converting enzyme, produced by actinomycetes. J. Antibiotics 38: 1813 1815, 1985

10) Yamato, M.; T. Koguchi, R. OKachi, K. Yamada, K. NaKayama \& H. Kase: K-26, a novel inhibitor of angiotensin I converting enzyme produced by an actinomycete K-26. J. Antibiotics 39: 44 52, 1986

11) Koguchi, T.; K. Yamada, M. Yamato, R. OKachi, K. NaKaYama \& H. Kase: K-4, a novel inhibitor of angiotensin I converting enzyme produced by Actinomadura spiculosospora. J. Antibiotics 39: 364 371,1986

12) CARmel, A.; S. Ehrlich-Rogozinsky \& A. YARON: A fluorimetric assay for angiotensin-I converting enzyme in human serum. Clin. Chim. Acta 93: 215 220, 1979

13) Udagawa, S. \& Y. Horie: Taxonomic notes on mycogenous fungi 1. J. Gen. Appl. Microbiol. 17: $141 \sim 159,1971$

14) Patchett, A. A.; E. Harris, E. W. Tristram, M. J. Wyvratt, M. T. Wu, D. Taub, E. R. Peterson, T. J. Ikeler, J. ten Broeke, L. G. PAyne, D. L. Ondeyka, E. D. Thorsett, W. J. Greenlee, N. S. Lohr, R. D. Hoffsommer, H. Joshua, W. V. Ruyle, J. W. Rothrock, S. D. Aster, A. L. Maycock, F. M. ROBINSON \& R. HIRSCHMANN: A new class of angiotensin-converting enzyme inhibitors. Nature 288: $280 \sim 283,1980$ 